\title{
カーボンナノチューブ複合電解ニッケルめっき皮膜の特性評価
}

\author{
酒井 豊明*, 中沢 昌夫*, 深瀬 克哉*, 若林 信一 **, 金子 紀男***
}

\section{The Characteristic Evaluations of Nickel/Multi-Wall Carbon Nano Tubes Composite Electroplating}

\author{
Toyoaki SAKAI*, Masao NAKAZAWA* , Katsuya FUKASE* , Shinichi WAKABAYASHI** and Norio KANEKO***
}

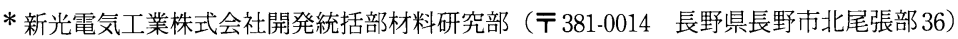 \\ ** 新光電気工業株式会社コンポーネント事業部（テ383-8581＼cjkstart長野県中野市草間1216-9） \\ *** 信州大学工学部物質工学科 (广 380-8553 長野県長野市若里 4-17-1) \\ * Material \& Process Research Dept., Research \& Development Div., Shinko Electric Industries Co., Ltd. (36 Kita-Owaribe, Nagano-shi, Nagano 381-0014) \\ ** Component Div., Shinko Electric Industries Co., Ltd. (1216-9 Kusama, Nakano-shi Nagano 383-8581) \\ *** Department of Chemistry and Material Engineering, Faculty of Engineering, Shinshu University (4-17-1 Wakasato, Nagano-shi, Nagano 380-8553)
}

\begin{abstract}
概要 マルチウォールカーボンナノチューブ（以下MWCNT）の優れた特性を活用する方法の1つとして，Ni內っき皮膜中 にMWCNTを均一に複合させた機能めっきの開発を行った。そして，作製した Ni/MWCNT 複合めっき皮膜中の MWCNT の機 械的特性抢よび熱特性に与える影響について調査した。得られた Ni/MWCNT複合めっき皮膜では, MWCNTを含まないNi単

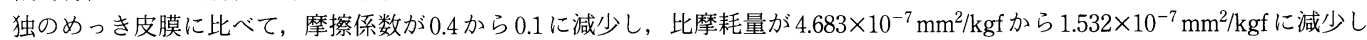
た。また，熱の放射率は，3 30 $\mu \mathrm{m}$ の波長範囲で，最大 0.89 を示すとともに，ほぼ一定の高い值を維持し，ヒートシンクとし て熱抵抗を減少させる効果を有していることがわかった。
\end{abstract}

\begin{abstract}
In this study, Ni/MWCNT composite electroplating was developed with a dispersed MWCNT Ni plating bath. The MWCNT was dispersed uniformly in the bath by a dispersion material and the Ni/MWCNT composite was electrodeposited from the dispersed MWCNT nickel plating bath. The $\mathrm{Ni}$ /MWCNT composite electroplating obtained at the optimum conditions showed flat and smooth surfaces. The Ni/MWCNT composite electroplating obtained in this study showed excellent mechanical and thermal characteristics. This Ni/MWCNT composite plating also demonstrated outstanding wear characteristic as sliding contacts. Especially it had an outstanding thermal characteristic of emissivity, in the broad wavelength range and dissipated the heat generated in the thermal chamber effectively. Maximum emissivity reached 0.89 (wavelength : $3 \sim 30 \mu \mathrm{m}$ ). Additionally, it maintained a high fixed value for that wavelength. It had the effect of decreasing heat resistance as a heatsink.
\end{abstract}

Key Words: Carbon Nano Tube, Dispersion Material, Composite Plating, Frictional Coefficient, Wear Characteristic, Emissivity, Conductivity, Heatsink

\section{1. 緒 言}

近年，ナノスケールの物質や構造制御を行うナノテクノ ロジの分野が急速に発展しつつある。カーボンナノチュー ブはナノメートルオーダーの代表的な物質であり，今後の ナノテクノロジの基盤になる物質として注目を集めている。 カーボンナノチューブは, 熱特性・機械的特性・電気的特 性において非常に優れた性質を有しており，将来の電子部 品や半導体分野のみならず，医療やバイオなどの多岐にわ たる分野においても，大きな期待を集めており，各分野で ブレークスルーをむたらす可能性を秘めている。

本報では, 優れた特性を持つマルチウォールカーボンナ ノチューブをニッケルめっき液中に均一に分散させた後に 電解めっきを行うことでめっき皮膜中に均一に共析させ,
ニッケル/マルチウォールカーボンナノチューブ複合めっ き皮膜を作製した。

マルチウォールカーボンナノチューブを樹脂やめっき皮 膜に複合させる研究例はすでに報告されている(1) 5)。それ らの報告例によると機械的特性の改善として摺動性や硬 度，また熱特性の改善として熱伝導率についての検討がさ れている。また，エミッ夕に利用して，電界放出電子源に 応用する技術も検討されている。

本研究では，作製したマルチウォールカーボンナノ チューブ複合めっき皮膜の形状について調へ，機械的特性， 熱特性を評価した。得られた複合めっき皮膜は，優れた熱 の放熱性を有しており，チップにヒートシンクとして搭載 した場合に，発生した熱を効率良く放散できることが判明 したので報告する。 


\section{2. 実験装置および方法}

本実験に用いたカーボンナノチューブは，マルチウォー ルカーボンナノチューブであり，以下MWCNTと略す。今 回開発したNi/MWCNT複合めっき皮膜は, 以下の条件で作 製し評価した。陽極，陰極の極間は $10 \mathrm{~cm}$ として，それぞ れにニッケル板と銅板を用いた。陰極はマスキングテープ を用いて有効面積が $18 \mathrm{~cm}^{2}$ になるよう面積規制を行った。 めっき槽の概要を Fig. 1 に簡略化して示す。めっき浴は, スターラー擋挥を行うとともに, 摇動装置を用いて両電極 を上下に $90 \mathrm{~cm} / \mathrm{min}$ で摇動させた。浴温 $50^{\circ} \mathrm{C}$ で電流規制法 により膜厚 $20 \mu \mathrm{m}$ のめっき皮膜を得た。めっき皮膜の評価 は，FE-SEMによる形状観察，超深度形状測定顕微鏡によ る表面粗度測定，日本電色工業製デンシトメータ ND-1に よる光沢度測定を行った。皮膜中のMWCNT含有量測定に は, ベックマン・コールター社製サブミクロン粒子アナラ イザーN5を用いた。熱特性の分析としては, 光学的零位 方式によるダブルビームの赤外分光光度計を用いた日本分 光製 EM-101型の放射特性測定装置を使用した。熱伝導率 の測定には，真空理工製熱定数測定装置PIT-1を用いた。 機械的特性の評価としては, ビッカース硬度計による硬度 測定およびデーバー式摩耗試験機を用いた摩耗試験を行っ た。なお，本研究で用いた MWCNTは, Fig. 3(a)に示すよ うに, 径 $0.15 \mu \mathrm{m}$, 長さ $10 \sim 20 \mu \mathrm{m}$ オーダーの寸法を有して いる。

\section{3. 実験結果および考察}

\section{1 めっき液の調整および皮膜生成方法}

微粒子を溶液中で分散させ, 凝集させずに均一な懸濁液 の状態を保つことは, 微粒子が均一に分散した複合めっき 皮膜を得る上で重要な因子である。したがって, めっき液 中に微粒子を凝集させることなく分散させるための分散剤 の選択が重要となる。本研究では, めっき液と分散剤との 適合性を検討することにより, MWCNTのぬれ性が良好で あり, かつめっき夜中にて MWCNT が凝集することのない 分散剂を選択した。これを使用して MWCNT 分散めっき液 を調整した。なお，めっき皮膜は，MWCNTの共析により 粗い表面形状で成長するため, 皮膜の平滑化を促進させる ための平滑化剂を添加した。基本浴組成を Table 1 に示す。

\section{2 めっ皮膜の構造観察}

電流規制法により得られた Ni/MWCNT 複合めっきの断面 形状の写真を Fig. 2 に示す。電流密度が $1,3 \mathrm{~A} / \mathrm{dm}^{2}$ の場合に は, 緻密で平滑な Ni/MWCNT複合めっき皮膜を得ることが できた。しかし, 電流密度 $5,10 \mathrm{~A} / \mathrm{dm}^{2}$ で電析させた場合に は，皮膜表面が凹凸である粗な皮膜が析出した。

一般的に, 電気伝導性の良好な分散粒子は, 陰極上に析 出した金属の表面に吸着して共析すると, それ自身が陰極 の一部になるため, 粒子表面にも金属が析出する。電気伝

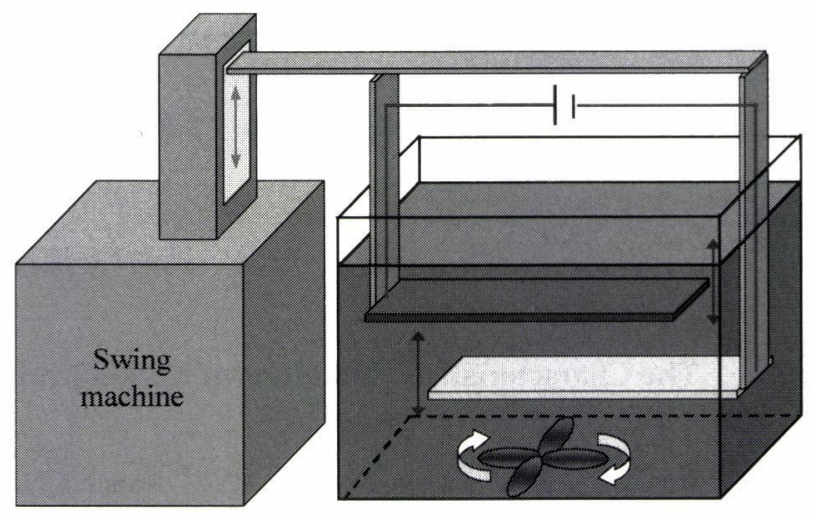

Fig. 1 A schematic description of composite electroplating equipment

Table 1. Composition of Ni/MWCNT composite electroplating bath

$\begin{array}{lr}\text { Nickel (II) sulfate hexahydrate: } & 100 \mathrm{~g} / \mathrm{L} \\ \text { Nickel (II) chloride hexahydrate: } & 50 \mathrm{~g} / \mathrm{L} \\ \text { Boric acid: } & 30 \mathrm{~g} / \mathrm{L} \\ \text { Saccharin sodium: } & 1 \mathrm{~g} / \mathrm{L} \\ \text { 2-Butyn-1,4-diol: } & 0.4 \mathrm{~g} / \mathrm{L} \\ \text { Dispersant: } & 1 \sim 6 \mathrm{~g} / \mathrm{L}\end{array}$

Dispersant: Main chain is alkynedior, it has Oxyethylene side chain at least $20 \mathrm{wt} \%$ in the molecule.
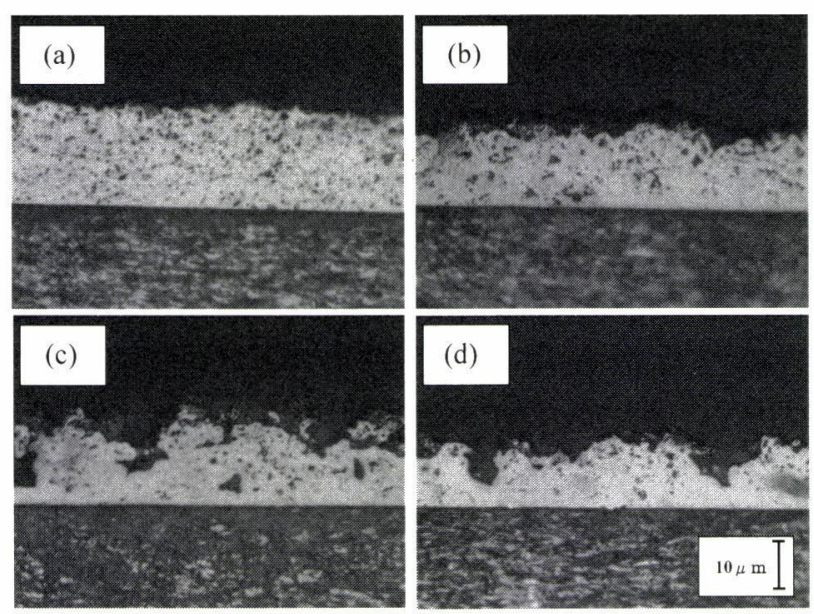

Fig. 2 Effect of Current density on the Ni/1000MWCNT composite electroplatings. (a) $1 \mathrm{~A} / \mathrm{dm}^{2}$, (b) 3 $\mathrm{A} / \mathrm{dm}^{2}$, (c) $5 \mathrm{~A} / \mathrm{dm}^{2}$, (d) $10 \mathrm{~A} / \mathrm{dm}^{2}$

導性粒子は金属皮膜に共析されやすいが，大きな粒子や凝 集した粒子が析出金属表面に吸着した場合には，共析粒子 にも金属が析出するので, 表面の粗いめっき皮膜が得られ

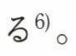

本研究では, 分散微粒子にMWCNTを用いており, その 電気伝導性がきわめて優れていることから，MWCNT上に は金属が直接析出することになる。したがって, MWCNT が皮膜に複合されて凸形状になった部位は, 電流が集中し て金属が析出するため, 低電流密度よりも高電流密度で電 

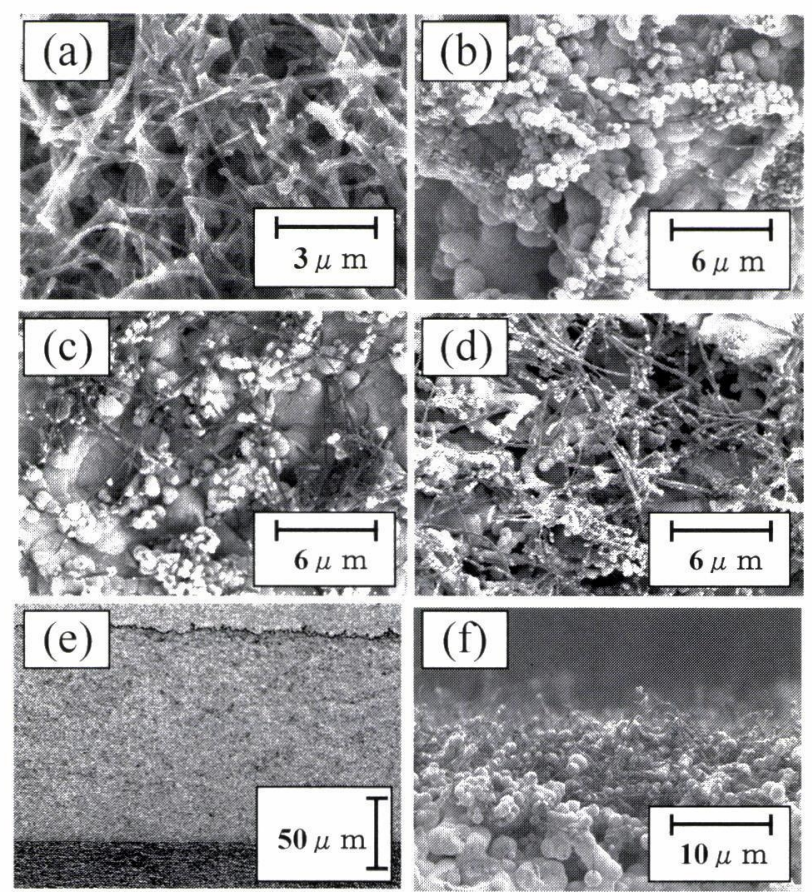

Fig. 3 SEM-images of MWCNT and Ni/MWCNT composite platings electrodeposited at $1.0 \mathrm{~A} / \mathrm{dm}^{2}$. (a) MWCNT, (b) Ni/100MWCNT, (c) Ni/500MWCNT, (d) $\mathrm{Ni} / 1000 \mathrm{MWCNT}$, (e) A cross sectional view of the Ni/1000MWCNT (150 $\mu \mathrm{m}$ thickness), (f) A Surface side of the cross sectional view of the $\mathrm{Ni} /$ 1000MWCNT

析させた場合の方が，粗い皮膜が得られたと考えられる。 めっき浴中の MWCNT の混合量を $100,500,1000 \mathrm{mg} / \mathrm{L}$ と変 化させた浴から, 電流密度 $1 \mathrm{~A} / \mathrm{dm}^{2}$ で電析させて得られた Ni/MWCNT 複合めっき皮膜の表面外観㧍よび断面形状の SEM写真を Fig. 3 に示す。得られた皮膜を以下 Ni/100MWCNT, Ni/500MWCNT, Ni/1000MWCNTと表記す る。皮膜表面を観察すると, 皮膜上に露出したMWCNTに は部分的に粒形状の Ni が析出していることが確認できる。 複合めっき皮膜が最も平滑となり, MWCNT 含有量が最大 となった条件で, めっき膜厚を $150 \mu \mathrm{m}$ まで成長させても Fig. 3(e)に示すような，均一な分散めっき皮膜が得られた。 その表面には，Fig. 3(f)に示すように，MWCNTが突き出た 形状をしている様子が観察できる。電流密度 $1 \mathrm{~A} / \mathrm{dm}^{2}$ で電 析させて得られた Ni/MWCNT複合めっき皮膜中の MWCNT 含有量とめっき浴中の MWCNT 混合量の関係を Fig. 4 に示 す。Ni/MWCNT 複合めっき皮膜中の MWCNT 含有量は, 浴 中の MWCNT 混合量を増加するに従って増大した7)。

$\mathrm{Ni} / \mathrm{MWCNT}$ 複合めっき皮膜の表面粗度に及ぼす電析時の 電流密度，およびめっき浴中MWCNT 混合量の影響を Fig. 5 に示す。電析時の電流密度は低電流密度であるほど, 皮 膜の表面粗度は小さくなった。また, 皮膜表面粗度は, 同 一の電流密度に扔いて浴中の MWCNT 混合量が増加するほ ど小さくなった8)。これは，浴中に混合させた MWCNTの 混合量が増加すればするほど，MWCNTが陰極に接触する

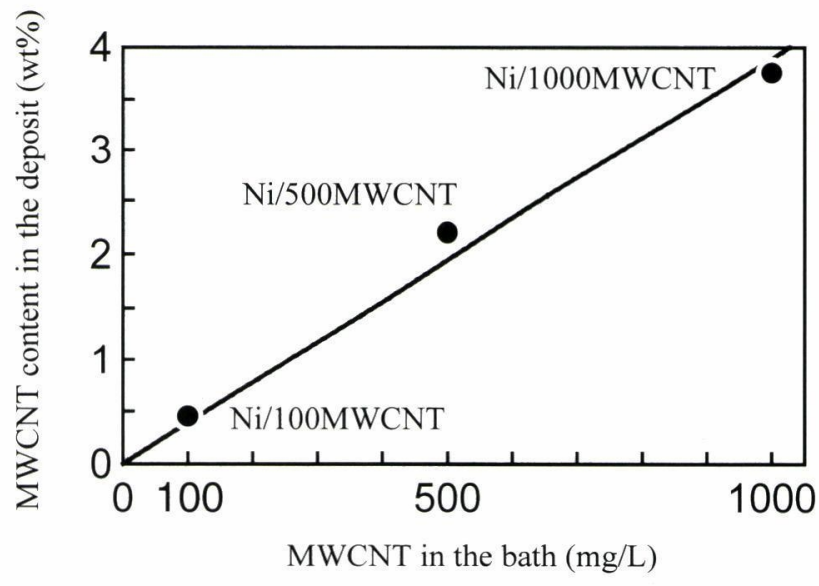

Fig. 4 Effect of MWCNT concentration in the solution on the MWCNT content in the deposits

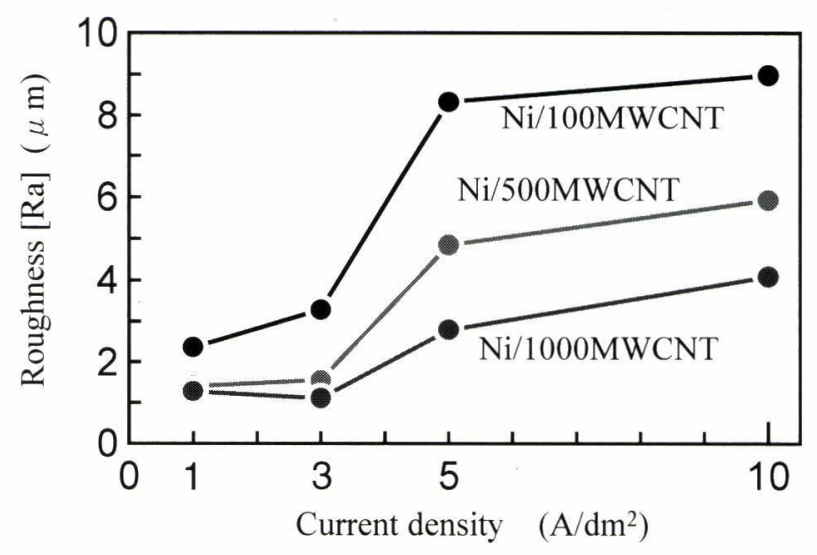

Fig. 5 Effect of current density and MWCNT concentration in the solution on the roughness of $\mathrm{Ni} / \mathrm{MWCNT}$ composite electroplatings

確率が高くなるためと考えられる。つまり，MWCNTが陰 極に複合されると一時的にその筒所は凸形状となるが，浴 中における MWCNT混合量が多い上陰極との接触する量が 増える結果, MWCNT の複合した周囲の山部箇所にも直ち にMWCNT が複合されることで, 凹凸の比較的少ない複合 めっき皮膜が形成されたと推測できる。

MWCNT との比較実験として, 直径が $0.1 \mu \mathrm{m}$ または $10 \mu \mathrm{m}$ の球形状カーボンブラック（以下 CBで表記）を MWCNT の場合と同様の方法で Ni めっき皮膜中に共析させ て, CB 複合めっき皮膜を得た。CB Table 1 に示す組成の めっき液中に $1000 \mathrm{mg} / \mathrm{L}$ の割合で混合しためっき浴から， 電流密度 $1 \mathrm{~A} / \mathrm{dm}^{2}$ で電析させて得られた複合めっき皮膜を それぞれ以下 $\mathrm{Ni} / 1000 \mathrm{CB}(0.1)$ 拈よび $\mathrm{Ni} / 1000 \mathrm{CB}(10)$ と.表記す る。得られた $\mathrm{CB}$ 複合めっき皮膜の外観形状を観察した SEM 写真を Fig. 6 に示す。粒径が $1 \mu \mathrm{m}$ 以下の $\mathrm{CB}(0.1)$ の場 合には, めっき浴中にて凝集させずに均一な毾濁液の状態 を保つことが困難であり, Ni/MWCNT 複合めっき皮膜と同 様の建浴方法および電析条件では, 皮膜中の微粒子が均一 かつ表面が平滑な複合めっき皮膜を得ることは困難であっ た。また，粒径が $10 \mu \mathrm{m}$ の $\mathrm{CB}(10)$ を分散粒子として用いた 

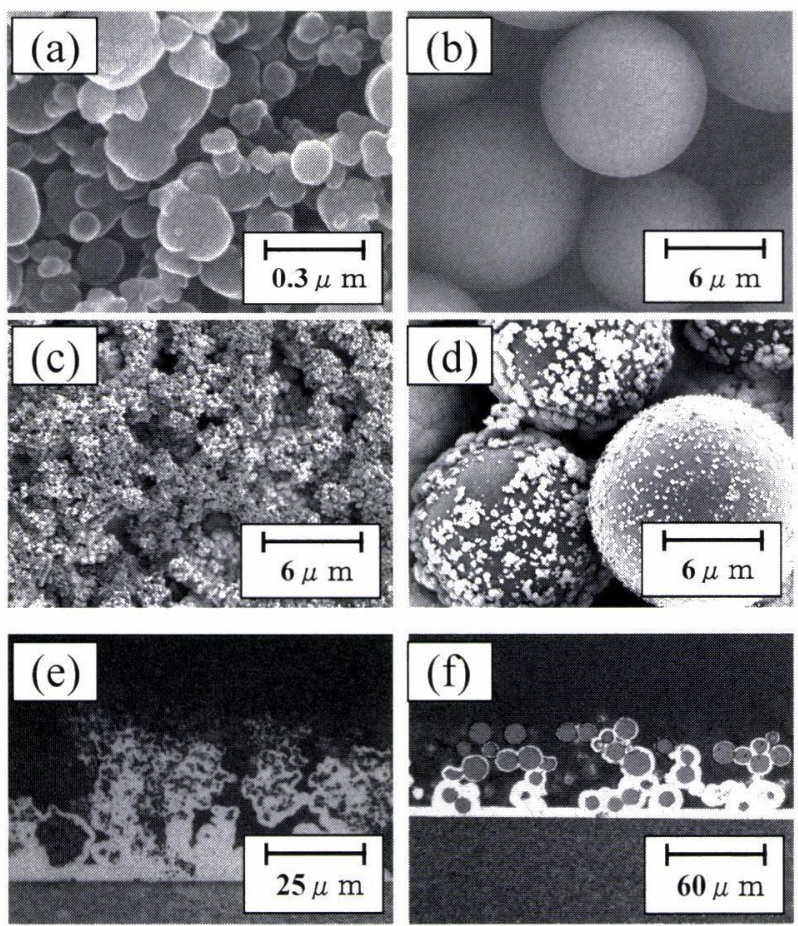

Fig. 6 SEM-images of $\mathrm{CB}(0.1), \mathrm{CB}(10)$ and $\mathrm{Ni} / \mathrm{CB}$ composite platings electrodeposited at $1.0 \mathrm{~A} / \mathrm{dm}^{2}$. (a) SEM-images of $\mathrm{CB}(0.1)$, (b) SEM-images of $\mathrm{CB}(10)$, (c) Ni/CB(0.1), (d) Ni/CB(10), (e) A cross sectional view of the $\mathrm{Ni} / \mathrm{CB}(0.1)$, (f) A cross sectional view of the $\mathrm{Ni} / \mathrm{CB}(10)$

場合には，そのサイズがめっき皮膜への共析に直接的に影 響を及ぼし，表面粗度の大きな皮膜となった。

\subsection{MWCNT複合めっき皮膜の機械的特性}

\subsection{1 耐摩耗特性}

本研究にて作製したMWCNT複合めっき皮膜の機械的特 性の評価として, 相手材にSKD11を用いて摩擦係数および 比摩耗量, またビッカース硬度を測定した。結果をTable 2 にまとめて示す。マトリックスとなる $\mathrm{Ni}$ めっき皮膜のみの 硬度は, $558.3 \mathrm{Hv}$ であるが, Niめっき皮膜中の MWCNT 含 有量の增大とともに硬度は増し， $3.8 \mathrm{wt} \%$ MWCNT では $834.7 \mathrm{Hv}$ を示した。

摩擦係数および比摩耗量の値は, Niめっき皮膜と比較し て, 皮膜中の MWCNT 含有量が増大するに従っていずれも 小さくなり，どちらの特性もマトリックスの $\mathrm{Ni}$ めっき皮膜

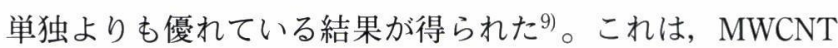
自体が硬いため, めっき皮膜中の MWCNT 含有量が増大す るほど，その複合めっき皮膜の硬度が高くなったことと， MWCNTが自己潤滑性を有していることによるものと考え られる。本複合めっき皮膜の表面にはMWCNTが多数露出 しており，Fig. 2 に示すように，その皮膜中にも多数の MWCNT が均一に共析している。この観察結果から MWCNTは，摺動する材料と良好に接触し，その自己潤滑 性により低摩擦抵抗が得られた之推測される ${ }^{10)}$ 。以上のこ とから，めっき皮膜中の MWCNT 含有量が増大するほど,
Table 2. Effect of MWCNT content in the deposit on the vickers hardness, ware resistance and frictional coefficient

\begin{tabular}{c|c|c|c}
\hline $\begin{array}{c}\text { MWCNT } \\
\text { contents }\end{array}$ & $\begin{array}{c}\text { vickers } \\
\text { hardness }(\mathrm{Hv})\end{array}$ & $\begin{array}{c}\text { ware resistance } \\
\left(\mathrm{mm}^{2} / \mathrm{kgf}\right)\end{array}$ & $\begin{array}{c}\text { Frictional } \\
\text { coefficient }\end{array}$ \\
\hline $\mathrm{Ni}$ & 558.3 & $4.683 \times 10^{-7}$ & 0.4 \\
$\mathrm{Ni} / 100 \mathrm{MWCNT}$ & 632 & $3.778 \times 10^{-7}$ & 0.3 \\
$\mathrm{Ni} / 500 \mathrm{MWCNT}$ & 793 & $1.242 \times 10^{-7}$ & 0.2 \\
$\mathrm{Ni} / 1000 \mathrm{MWCNT}$ & 834.7 & $1.532 \times 10^{-7}$ & $0.1 \sim 0.15$ \\
\hline
\end{tabular}



Fig. 7 Relationship between the Ni/MWCNT composite electroplatings and the emissivity

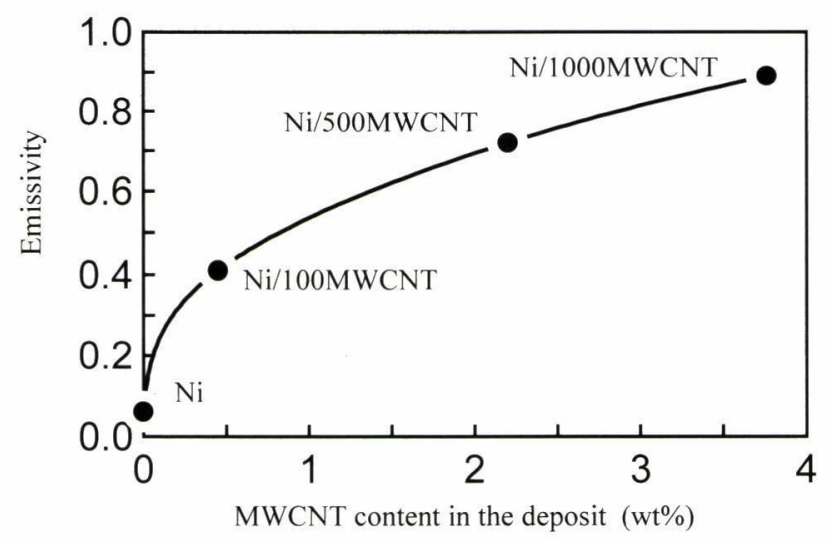

Fig. 8 Effect of MWCNT content in the deposit on the emissivity of wavelength at $10 \mu \mathrm{m}$

マトリックス金属の種類によらず耐摩耗性は向上すると考 えられる。

\section{$3.4 \mathrm{Ni} / \mathrm{MWCNT}$ 複合めっき皮膜の熱特性}

\section{4 .1 放射率}

めっき浴中への MWCNT 添加量を変化させ, 電流密度 $1 \mathrm{~A} / \mathrm{dm}^{2}$ で得られた Ni/MWCNT 複合めっき皮膜について熱


性測定装置を用いて物質の素材および表面状態に大きく依 存する放射率を測定した。試験は, 温度 $100^{\circ} \mathrm{C}$, 波長 3 $30 \mu \mathrm{m}$ の範囲で行った。Ni単独のめっき皮膜と Ni/MWCNT の放射率測定結果を Fig. 7 に示す。また，Ni/MWCNT 複合 めっき皮膜中の MWCNT 含有量と波長 $10 \mu \mathrm{m}$ における放射 率の関係をまとめた結果を Fig. 8に示す。 $\mathrm{Ni}$ 単独のめっき 
皮膜の放射率は，通常の金属と同等の低い值を示し， $3 \sim 30 \mu \mathrm{m}$ の波長範囲で放射率は 0.15 以下であった。これに 対して, Ni/1000MWCNT 複合めっき皮膜は, $3 \sim 30 \mu \mathrm{m}$ の波 長範囲でほぼ一定の高い放射率を有し, 波長 $10 \mu \mathrm{m}$ では放 射率 0.89 を示した。また, めっき皮膜中の MWCNT 含有量 が増加するにつれて放射率は増大した。MWCNTよりも粒 径の小さな $\mathrm{CB}(0.1)$ を複合させた $\mathrm{Ni} / 1000 \mathrm{CB}(0.1)$ との比較結 果をFig. 9 に示す。 $\mathrm{Ni} / 1000 \mathrm{CB}(0.1)$ は, 低波長側では放射率 0.8 程度の比較的高い值を示したが, 波長 $5 \mu \mathrm{m}$ 以上では 0.25 以下まで徐々に低下し, 高波長側では金属単体と同程 度の低い放射率であった。一方で, MWCNTよりも粒径の 大きな $\mathrm{CB}(10)$ を複合させた $\mathrm{Ni} / 1000 \mathrm{CB}(10)$ は，3 30 $\mu \mathrm{m}$ の波 長範囲でほぼ一定の放射率を保持したが, 全体的に低く 0.5 以下の放射率であった ${ }^{11)}$ 。

熱放射は，ランバートの法則から放射率が同一な物体で は，放射にかかわる面積が広いほど，その值は高くなる。 Ni/1000CB(0.1)の表面はNi/1000MWCNTに比へてて粗いため, 比表面積は広いと言える。しかし, 放射率は Ni/ 1000MWCNTの方が高いことから, MWCNT 固有の放射率 がCBのそれより高いものと推測される。

また，MWCNTを複合させためっき皮膜は，3３0 $\mu \mathrm{m} の$ 波長範囲でほぼ一定の放射率を有するのみならず，CB と 比較して非常に高い值を高波長側でも示すことから，CB りも少ない共析量で熱を効率良く外部に放射する特性を有 していると言える。

本研究で開発した Ni/MWCNT 複合めっき皮膜の表面粗

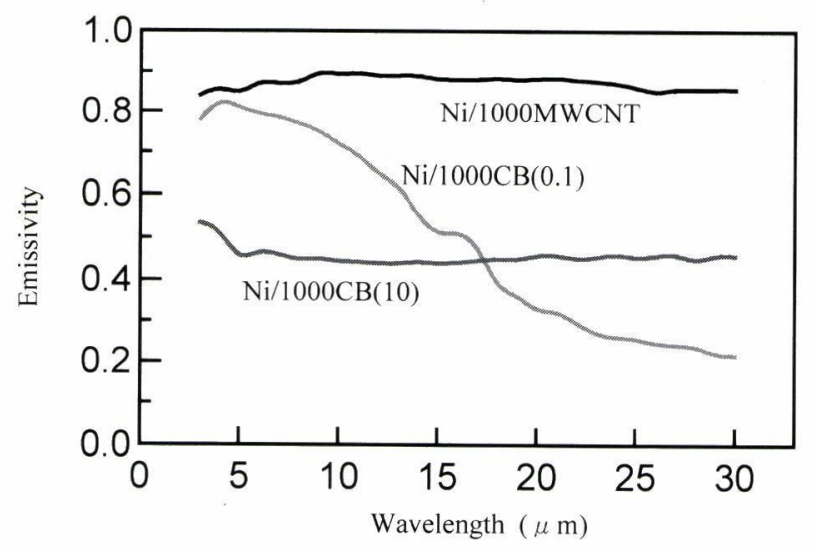

Fig. 9 Relationship between the emissivity of $\mathrm{Ni} / \mathrm{MWCNT}$ and $\mathrm{Ni} / \mathrm{CB}$ composite electroplatings

Table 3. Relationship between the roughness and luminous intensity of Ni/MWCNT composite electroplating

\begin{tabular}{c|c|c|c}
\hline $\begin{array}{c}\text { MWCNT } \\
\text { contents }\end{array}$ & $\begin{array}{c}\text { roughness [Ra] } \\
(\mu \mathrm{m})\end{array}$ & $\begin{array}{c}\text { Luminous } \\
\text { intensity }\end{array}$ & Emissivity \\
\hline $\mathrm{Ni}$ & 0.08 & 2.25 & 0.06 \\
$\mathrm{Ni} / 100 \mathrm{MWCNT}$ & 1.96 & 0.49 & 0.45 \\
$\mathrm{Ni} / 500 \mathrm{MWCNT}$ & 1.41 & 0.69 & 0.72 \\
$\mathrm{Ni} / 1000 \mathrm{MWCNT}$ & 1.28 & 0.83 & 0.89 \\
\hline
\end{tabular}

度と光沢度の関係を放射率と比較して Table 3 に示した。こ れより，MWCNT の浴中混合量が増大するほど，表面粗度 が小さくなり, 光沢度が増すことがわかった。また， Ni/MWCNT 複合めっき皮膜は, Fig. 2, 3に示したように, MWCNT が皮膜全体に均一に共析しており, 皮膜表面には MWCNTが露出する形状であることがわかる。

この Ni/1000MWCNTを $10 \%$ 硝酸に 10 秒間浸せき摇動さ せて，Ni/1000MWCNT の表面の Niをエッチングした後，放 射率を測定した結果をFig. 10 に示す。またそのエッチング した表面のSEM写真を Fig. 11 に示す。 Ni/1000MWCNT の 表面に対してエッチングを施しためっき皮膜の放射率は, エッチングを施さない皮膜と比較して $3 \sim 30 \mu \mathrm{m}$ の波長範囲 全域で低下する結果となった。

エッチングを施していないNi/1000MWCNTでは, MWCNTがめっき皮膜表面から露出するとともに, その上 にNiを媒体として別の Niに被覆されていないMWCNTが 共析していることがFig. 11(a)から確認できる。これに対し てNiをエッチングした場合には, Niめっき皮膜中に取り込 まれていた MWCNTが脱落したことが Fig. 11(b)で確認でき る。つまり, めっき皮膜の表面に $\mathrm{Ni}$ で被覆されていない MWCNT がエッチングで脱落し隇少したために, 放射率が 低くなったと考えられる。以上の結果から, めっき皮膜表 面からマトリックス金属に被覆されていないMWCNTが露 出している状態を形成させ, その露出量を増加させること が放射率の向上に有効な手段であると言える。

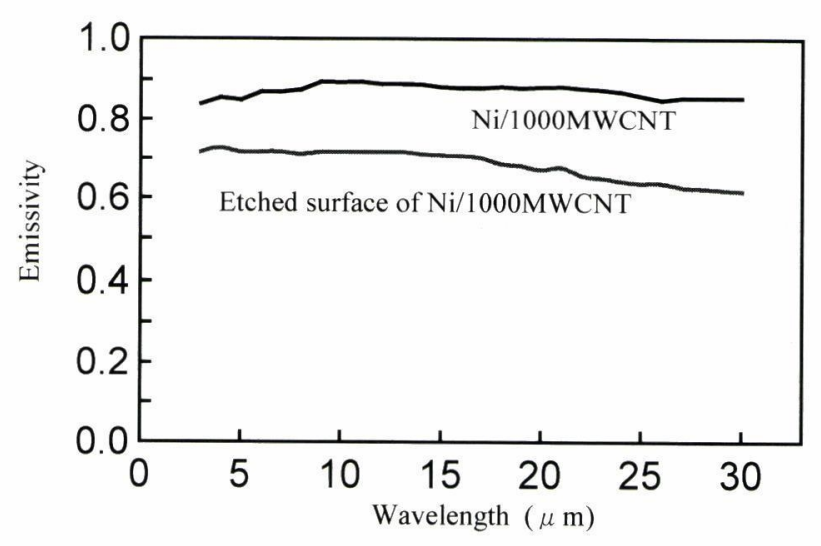

Fig. 10 Effect of plating surface on the emissivity

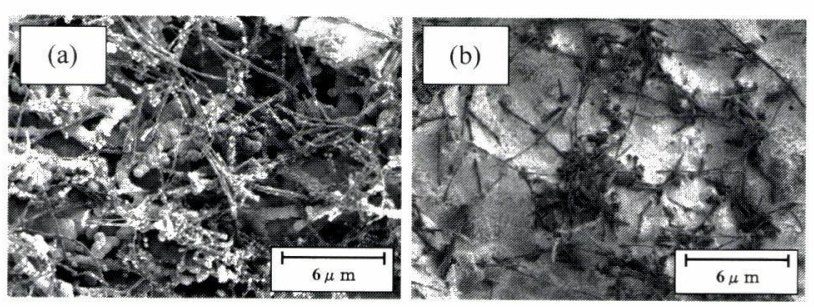

Fig. 11 SEM-images of the Ni/1000MWCNT composite electroplating and the etched surface of this composite electrodeposited at $1.0 \mathrm{~A} / \mathrm{dm}^{2}$. (a) $\mathrm{Ni} / 1000 \mathrm{MWCNT}$, (b) Etched surface of $\mathrm{Ni} /$ 1000MWCNT 
Table 4. Thermal conductivity and emissivity of $\mathrm{Ni} / \mathrm{MWCNT}$ composite electroplating

\begin{tabular}{l|c|c}
\hline & Ni & Ni/1000 MWCNT \\
\hline Temperature $\left({ }^{\circ} \mathrm{C}\right)$ & 25 & 25 \\
Density $\left(\mathrm{g} / \mathrm{cm}^{3}\right)$ & 8.899 & 8.644 \\
Specific heat $(\mathrm{J} / \mathrm{kg} \cdot \mathrm{K})$ & 447 & 447 \\
Diffusivity of heat $\left(10^{-5} \mathrm{~m}^{2} / \mathrm{s}\right)$ & 1.31 & 1.24 \\
Thermal conductivity $(\mathrm{W} / \mathrm{m} \cdot \mathrm{K})$ & 52.1 & 49.2 \\
Emissivity [wavelength: $10 \mu \mathrm{m}$ ] & 0.06 & 0.89 \\
\hline
\end{tabular}

\section{4 .2 熱伝導率}

放射率の低い $\mathrm{Ni}$ 単独の皮膜と放射率の高い $\mathrm{Ni}$ / 1000MWCNT 複合めっき皮膜の熱伝導率の測定結果をTable 4 に示す。なお，MWCNTを複合したNiめっき皮膜の比熱 は, 測定が困難であったため, 純 $\mathrm{Ni}$ の文献值を用いた ${ }^{12)} 。$ 熱伝導率の高いMWCNTをめっき皮膜に複合させることで, マトリックスの金属単独よりも熱伝導率が良好になること が予想された。しかしながら，本研究で測定した Ni/ 1000MWCNT の熱伝導率は，Ni 単独のめっき皮膜とほぼ同 等の值であった。MWCNTの有無にかかわらず熱伝導率が ほとんど変化しなかった原因については，熱伝導率の高い MWCNT 間に熱伝導率の低い Ni が存在する構造になってい るためと考えられる。したがって, 熱伝導率を向上させる ためには，Niめっき皮膜中に複合したMWCNT 同士が直接 連続的に接触し合うように，MWCNTをほぐした状態で共 析させるとともに，さらにMWCNTの含有量を増加するこ とが必要と考えられる。

\section{4 .3 放熱特性の評価}

熱放射性とともに熱伝導性も大きければ，パッケージや 筐体内部で発生した熱を，より速やかに外部に発散させる ことが可能である。本研究で開発した Ni/MWCNT複合めっ き皮膜は, マトリックスが金属であることから，少なくと もマトリックスと同等の熱伝導率を有している。したがっ て, 放熱媒体にNi/MWCNT 複合めっき皮膜を施すことで, 効率良く熱を放散させることが可能になる。ここでは，熱 伝導率が同等である放射率の高いNi/1000MWCNT 複合めっ き皮膜と，放射率が低い $\mathrm{Ni}$ めっき皮膜について，放射率の 違いによる冷却効果を, 機器内部空間の温度より評価し

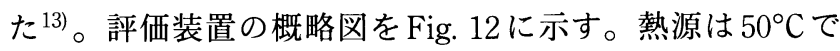
一定とした。筐体は, 熱源からの熱を熱伝導により直接 めっき皮膜に伝えにくいようにするため断熱性の高い物質

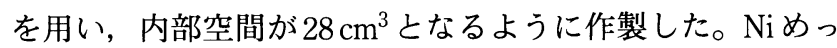
きおよびNi/1000MWCNT のそれぞれを銅上に $20 \mu \mathrm{m}$ 析出さ せ，銅材ごと断熱性筐体上部に熱が漏れることがないよう に設置し，それを熱抵抗測定用の風洞の中に入れて風速ゼ ロ. 同一外気温 $\left(26^{\circ} \mathrm{C}\right)$ の条件下で測定した。時間経過に対 する装置内部の温度（めっき皮膜の $10 \mathrm{~mm}$ 下部： $\mathrm{Tx}$ ）の 測定結果を Fig. 13 に示す。放射率が高い Ni/1000MWCNT めっき皮膜は, 放射率の低い $\mathrm{Ni}$ めっき皮膜と比較して, $\mathrm{T}_{\mathrm{x}}$

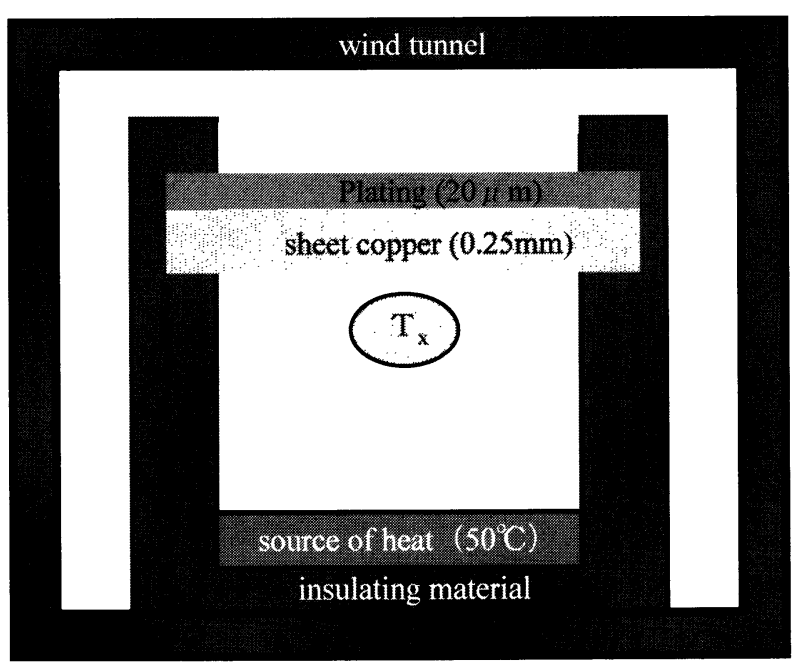

Fig. 12 A schematic description of the thermal radiation test equipment. The case capacity is $28 \mathrm{~cm}^{3}$. Plating thickness is $20 \mu \mathrm{m}$

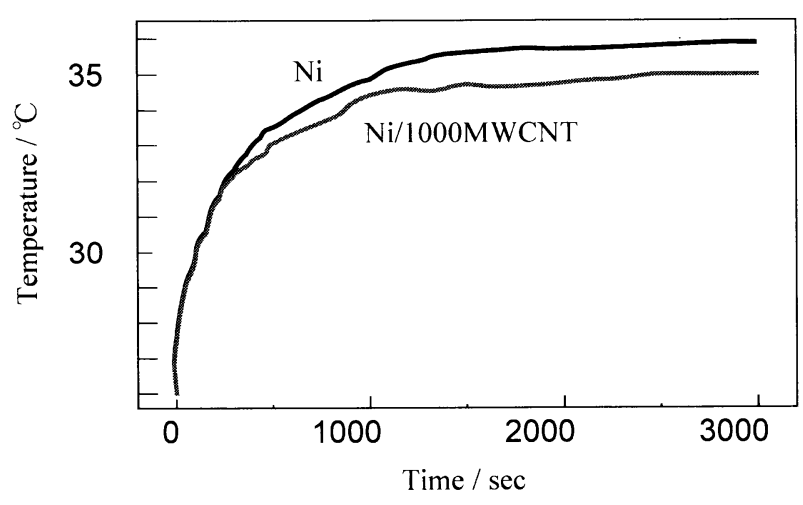

Fig. 13 The results of the thermal radiation tests for the Ni/MWCNT composite electroplating

における温度が時間の経過とともに $1 \sim 2{ }^{\circ} \mathrm{C}$ 程度低下した。 これは，熱源から発生して筐体内部にこもった熱を， $\mathrm{Ni} / \mathrm{MWCNT}$ 複合めっき皮膜の高い放射率によって外部に効 率良く放散したためと考えられる。

\section{4 .4 熱抵抗}

筐体内部の温度は，皮膜中にMWCNT を複合させること で，マトリックスとなるNiめっき皮膜よりも低下すること が判明した。そこで，半導体素子の温度上昇を抑制するこ とが可能であるかをFCBGA144Pin 構造を用いて評価した。 測定值としては, 熱抵抗 $\left(\theta_{\mathrm{ja}}\right)$ を求めた。熱抵抗測定条件お よびFCBGA144Pin 構造の模式図をそれぞれ Table 5, Fig. 14 に示す。また，得られた熱抵抗測定結果をFig. 15 に示し た。

放射率が高い Ni/1000MWCNT めっき皮膜は，放射率の低

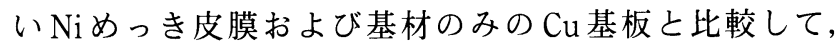
0 2 m/secの風速の範囲において $\theta_{\mathrm{ja}}$ が低下した。特に, 無 風状態での風速 $0 \mathrm{~m} / \mathrm{sec} に お け る \theta_{\mathrm{ja}}$ の值は, $3.8^{\circ} \mathrm{C} / \mathrm{W}$ 低下 した。これらの結果から，MWCNTをめっき皮膜に複合さ せることで，電子回路，特に微小な面積内で集中的に発生 
Table 5. Measurement conditions of thermal resistance

\begin{tabular}{l|c}
\hline PKG Size & $11.43 \times 11.43[\mathrm{~mm}]$ \\
Chip Size & $9.525 \times 9.525 \times 0.5[\mathrm{~mm}]$ \\
Board Layer & $2 \mathrm{LPCB}$ \\
Board Size & $114.3 \times 76.2 \times 1.57[\mathrm{~mm}]$ \\
Chip Power & $0.7 \mathrm{~W}$ \\
Air Flow Velocity & $0,0.5,1,2[\mathrm{~m} / \mathrm{s}]$ \\
Heat Spreader Size & $10 \times 10 \times 0.25[\mathrm{~mm}]$ \\
Method & Pulse \\
\hline
\end{tabular}

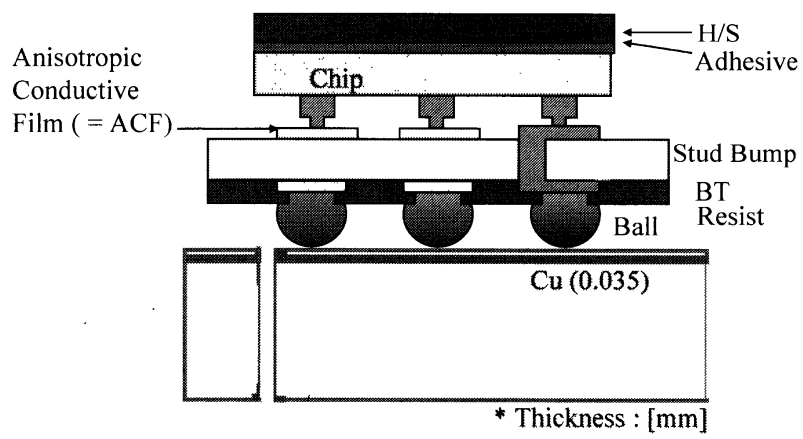

Fig. 14 FCBGA144Pin Structure

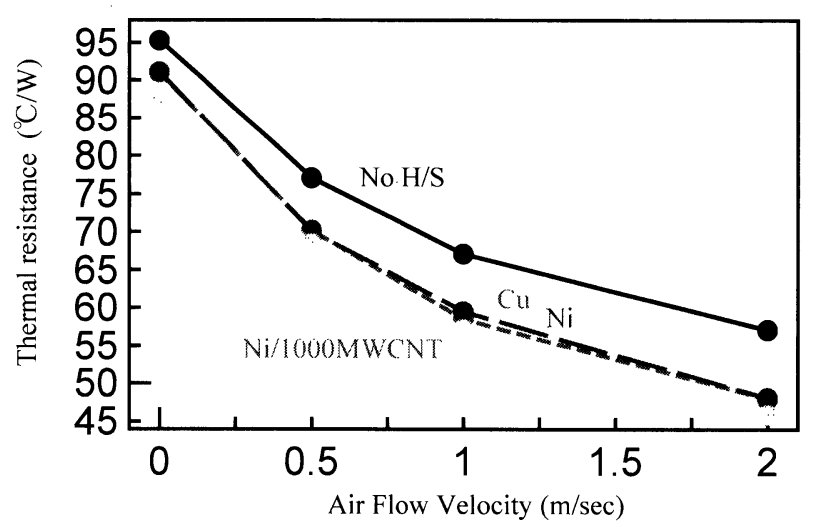

Fig. 15 The result of thermal resistance

した半導体チップの熱を外部空間へ効率良く放散させ，温 度上昇による動作不良や故障に陥る問題が改善されると期 待できる。

\section{4. 結 言}

本研究で開発した Ni/MWCNT 複合めっき皮膜は以下のよ うな特徴を有した。

• めっき浴中の MWCNT 混合量が増加するほど, 得られ る Ni/MWCNT 複合めっき皮膜中の MWCNT 含有量は増大 し, また電析時の電流密度が低電流密度であるほど, 皮膜 の表面粗度(Ra)が小さくなった。

・Niめっき皮膜と比へて Ni/MWCNT 複合めっき皮膜は, ビッカース硬度が増すとともに摩擦係数が減少する結果, 比摩耗量値が低下した。

・MWCNT の含有量 $4 \mathrm{wt} \%$ では, Ni めっき皮膜と Ni/ MWCNT の熱伝導率に大きな差が生じなかったのに対し， Ni/MWCNT の放射率は 0.06 から 0.89 に増加し，3 30 $\mu \mathrm{m}$ の
波長範囲でほぼ一定の高い値を示した。

・Ni/MWCNT 複合めっき皮膜の表面に露出した MWCNT は, Niめっきに被覆されていない状態であった。MWCNT の含有量が増して表面からの Niに被覆されていない MWCNT の露出が多くなるほど，熱放射率が高くなった。 これにより，放熱特性が向上した。FCBGA144pin 構造の ヒートシンクに応用した場合の熱抵抗は，Ni 単独のめっき

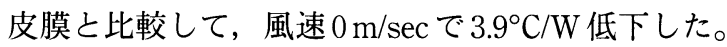

MWCNT 複合めっきは，金，銀，銅，スズなどへのマト リックスの変更, MWCNT の形状寸法および含有量増減な どの諸条件を変えることで，さらに優れた機能を発現する 可能性を有しており, 今後の開発が期待される。

今回実験に供した MWCNTは, 遠藤守信教授（信州大 学）よりご提供いただいた。

(2004.4.19-受理)

\section{文献}

1) S. Dong, X. Zhang: "Mechanical properties of Cu-based composites reinforced by carbon nanotubes", Trans Nanferrous Met. Soc. China, Vol. 9, No. 3, pp. 457-461, 1999

2) S.-N. Li, S.-Z. Song, T.-Q. Yu, H.-M. Chen, Y.-S. Zhang, J.-L. Shen: "Properties and Structure of Magnesium Matrix Composite Reinforced with CNTs", J. Wuhan Univ. Technol. Mater. Sci. Ed., Vol. 19, No. 1, pp. 65-68, 2004

3) 上利泰幸, 紙谷畑恒雄: “熱伝導性 100 倍樹脂で金属代替 へ”, セラミックス, Vol. 54, No. 3, pp. 49-57, 2003

4) “エミッタ及びその製造方法”，特開 2000-182509

5) “電界放出型冷陰極, その製造方法及び真空マイクロ装 置”, 特開 2001-283716

6）古川直治：“複合めっきの現状と将来”，表面技術，Vol. 51, No. 11, pp. 1056-1061, 2000

7) X. H. Chen, F. Q. Cheng, S. L. Li, L. P. Zhou, D. Y. Li: "Electrodeposited nickel composites containing carbon nanotubes", Surface and Coatings Technology, Vol. 155, No. 2/3, pp. 274-278, 2002

8）林 秀考: “複合めっきの共析メカニズム”, 表面技術, Vol. 51, No. 11, pp. 1062-1068, 2000

9) X. H. Chen, J. C. Peng, X. Q. Li, J. X. Wang, F. M. Deng, W. Z. Li: "Tribological behavior of carbon nanotubes-reinforced nickel matrix composite coatings", J Mater Sci Lett, Vol. 20, No. 22, pp. 2057-2060, 2002

10) 中尾英弘 : “無電解ニッケル-PTFE 複合めっきの耐摩耗性”, 表面技術, Vol. 51, No. 11, pp. 1085-1087, 2000

11）高橋通泰：“熱放射性表面処理材”, 特開2002-226783

12）日本熱物性学会, 編：“熱物性ハンドブック”, 養賢堂発 行, 1990

13）平野康雄, 渡瀬岳史, 満田正彦：“放熱特性に優れた表面 処理鋼板”，表面技術，Vol. 54, No. 5, pp. 334-337, 2003 